\title{
Society pages
}

\section{Gifts and Grants to FFPS}

FFPS is most grateful for the gifts of $£ 25$ and over listed below and also for many smaller donations between 15 October and 31 December 1984.

\section{Oryx $100 \%$ Fund}

St Katharine's Fund-earmarked for East Africa Wildlife Society

Sale of secondhand books at FFPS meetings

A.B. Stobart

\section{Mountain Gorilla Project}

Lord and Lady Forbes

I.E. Wenlock

G.J. Noble

E.W.W. Bernard

M.S. Bellis

Mary Rae

E.N. Portelly

Mersey Valley Wardens

\section{Bat Project}

Sir John Leslie

\section{General Fund}

New Moorgate Trust Funds

Anonymous-covenanted

Ofenhein and Cinderford Charitable

Trust

St Katharine's Fund

Conder Conservation Fund

Bruce Coleman Ltd

Services Sound \& Vision Corporation

\section{Legacies}

Estate of E.A.B. Pratt

Estate of L. Sherriff (residue)
500.00

69.42

\section{London Pond Survey}

The FFPS/Greater London Council survey of London's ponds is now complete. Tom Langton, the biologist employed to carry out the work has written a report, which will be published in the July Oryx.

$5,000.00$ $4,000.00$

$1,400.00$

400.00

250.00

156.52

40.00

126

\section{Mountain Gorilla Project}

This sticker and the new poster reproduced on page 125 were specifically designed to help fundraising and publicity for the Mountain Gorilla Project. These and other aids, including slide packs, collecting boxes and information leaflets, are available to anyone wishing to help raise funds for the project. Please write to the FFPS office if you are able to help.

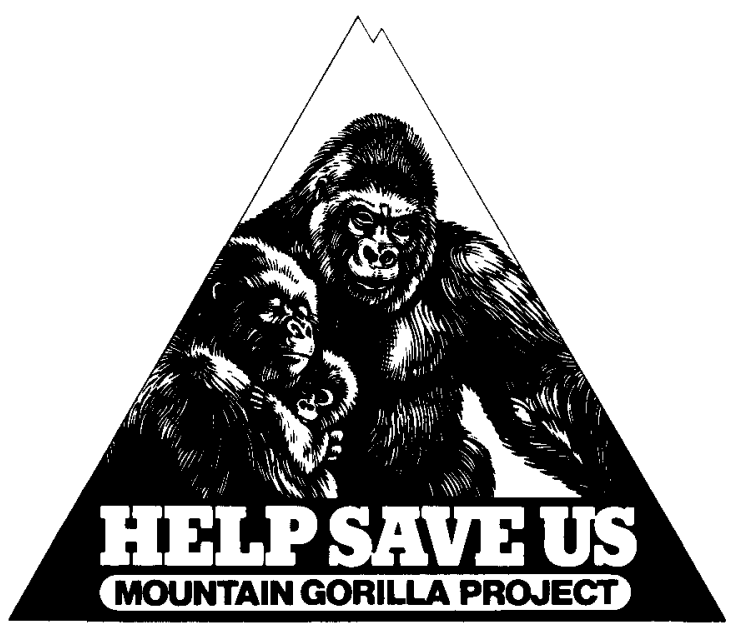

\section{Kenya conservation centre}

Elsamere, the home of the late Joy Adamson, is now a residential conservation centre, providing accommodation and other facilities for individual scientists or small groups who wish to study in Kenya. The centre is open to any bona fide research worker or university group studying biological or geological science, writers or filmmakers working on the natural history of Kenya, members of conservation tours, and members of recognised scientific societies. Details: The Warden, Elsamere Conservation Centre, POBox 4, Naivasha, Kenya.

\section{Jersey Zoo expands training programme}

The Wildlife Preservation Trust's training programme at its zoo in Jersey in the Channel Islands has extended its scope. In addition to the original 16-week courses it now runs 10-week and 6week courses for government-sponsored Oryx Vol 19 No 2 


\section{Society pages}

personnel, zoo staff and university graduates or undergraduates with good practical experience. Government-sponsored applicants from developing countries may be awarded scholarships to cover training costs. Details: Dr D.R. Waugh, Training Officer, Jersey Wildlife Preservation Trust, Les Augrès Manor, Trinity, Jersey, Cl.

\section{A holiday to help conservation in the Falklands}

Salen Lindblad have recently announced a special trip to Antarctica in their famous cruise ship, the Lindblad Explorer, in aid of conservation in the Falkland Islands.

In December 1985 the Explorer will leave the southern extremities of South America for a 21 day journey to Antarctica, South Georgia and the Falklands. For every passenger who goes on the trip as a result of this promotion, Salen Lindblad have agreed to give $£ 250$ to the Falkland Islands Foundation. By making this trip you would not only have the holiday of a lifetime, but you would be greatly helping the Foundation in its conservation programme, for which it desperately needs money.

Salen Lindblad and the Falkland Islands Foundation are holding a special meeting in the Large Meeting Room of the London Zoological Society offices, Regent's Park, London NW1 on Thursday 23 May at $6.30 \mathrm{pm}$ to explain the trip and the work of the Foundation in more detail. Admission is free, wine will be served and slides of previous Antarctic journeys aboard the Lindblad Explorer will be shown. It is hoped that Sir Peter Scott will introduce the meeting.

If you would like to attend on 23 May, please contact John Formston, Salen Lindblad Cruising, 6 Shepherd Street, London W1 (Tel: 01499 7522). If you cannot attend but would like further information, please contact John Formston (mentioning that you heard about the trip through Oryx) or Simon Lyster, Secretary, Falkland Islands Foundation, Panda House, 1113 Ockford Road, Godalming, Surrey GU7 1QU (Tel: 04868 20551).

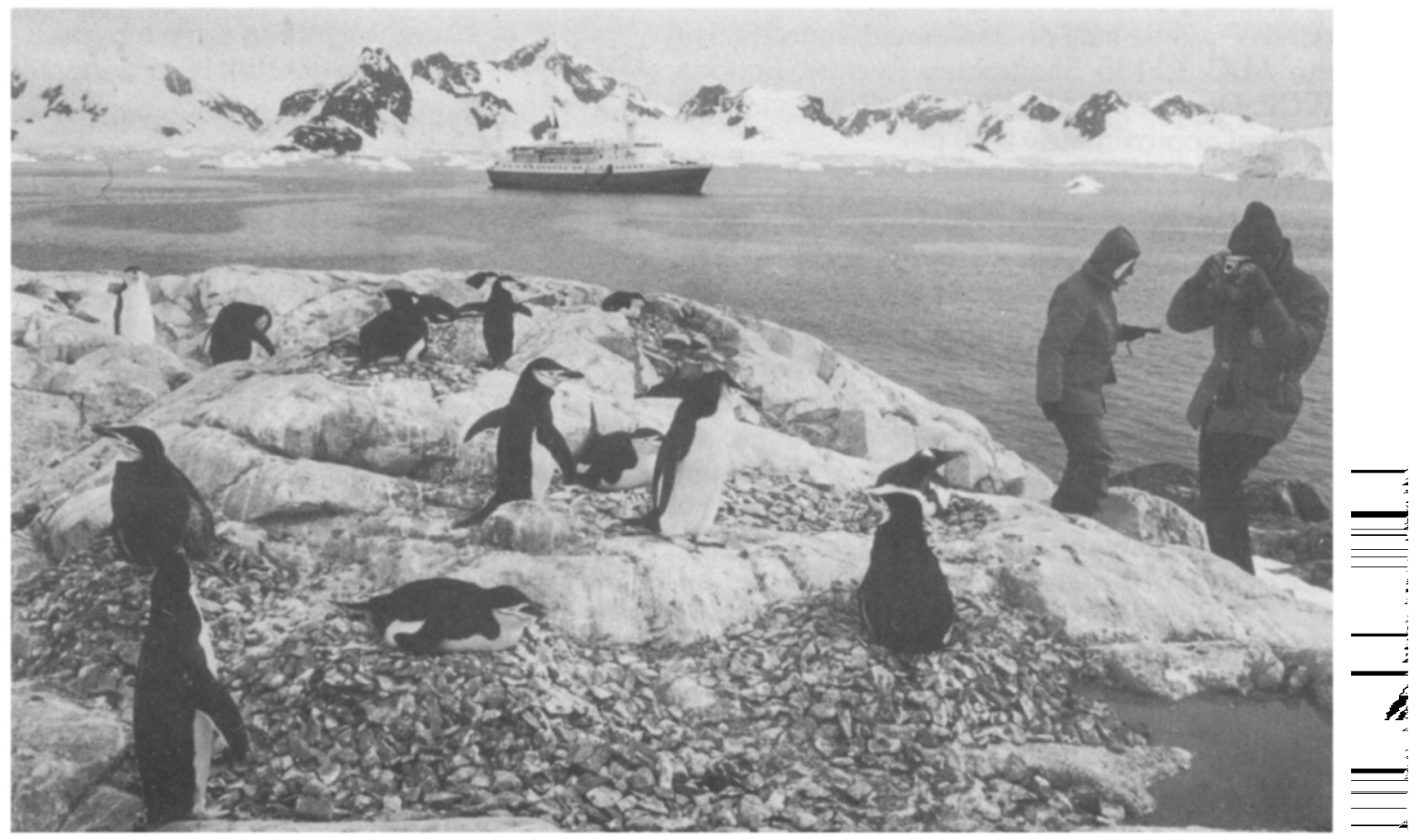

